Published in "Geomorphology 87(4): 337-351, 2007"

which should be cited to refer to this work.

\title{
Reconstructing spatio-temporal patterns of debris-flow activity using dendrogeomorphological methods
}

\author{
Michelle Bollschweiler ${ }^{\mathrm{a}, *}$, Markus Stoffel ${ }^{\mathrm{a}}$, Melanie Ehmisch ${ }^{\mathrm{b}}$, Michel Monbaron ${ }^{\mathrm{a}}$ \\ a Laboratory of Dendrogeomorphology, Department of Geosciences, Geography, University of Fribourg, 1700 Fribourg, Switzerland \\ ${ }^{\mathrm{b}}$ Department of Physical Geography, Geosciences/Geography, J. W. Goethe-University, 60054 Frankfurt am Main, Germany
}

\begin{abstract}
Debris flows are a major threat in many parts of the Alps, where they repeatedly cause severe damage to infrastructure and transportation corridors or even loss of life. Nonetheless, the spatial behavior of past debris-flow activity and the analysis of areas affected during particular events have been widely neglected in reconstructions so far. It was therefore the purpose of this study to reconstruct spatio-temporal patterns of past debris flows on a forested cone in the Swiss Alps (Bruchji torrent, Blatten, Valais). The analysis of past events was based on a detailed geomorphic map (1:1000) of all forms related to debris flows as well as on tree-ring series from 401 heavily affected trees (Larix decidua Mill. and Picea abies (L.) Karst.) growing in or next to deposits. The samples were analyzed and growth disturbances related to debris-flow activity assessed, such as tangential rows of traumatic resin ducts, the onset of reaction wood or abrupt growth suppression or release.

In total, 960 growth disturbances were identified in the samples, belonging to 40 different event years between A.D. 1867 and 2005. In addition, the coupling of tree-ring data with the geomorphic map allowed reconstruction of eleven formerly active channels and spatial representation of individual events. Based on our results we believe that before 1935, debris flows preferentially used those channels located in the western part of the cone, whereas the eastern part of the cone remained widely unaffected. The spatial representation of the 40 events also allowed identification of five different spatial patterns for debris flows at the study site.
\end{abstract}

Keywords: Debris flows; Dendrogeomorphology; Tree ring; Geomorphic mapping; Spatial patterns; Abandoned channels

\section{Introduction}

Debris flows are a common mass-movement process in mountainous regions where they frequently leave traces in the landscape. At the mouth of gullies or torrent valleys, active debris-flow torrents build cone-shaped debris

\footnotetext{
* Corresponding author. Tel.: +412630092 49; fax: +41 263009746.

E-mail address: michelle.bollschweiler@unifr.ch
}

(M. Bollschweiler). accumulations and characteristic depositional forms such as lobes and levees. The processes and forms related to debris-flow activity have extensively been described in the literature (Jakob and Hungr, 2005). Previous investigations repeatedly focused on e.g., the flow behavior and rheology (Costa, 1984; Johnson and Rodine, 1984; Costa, 1988; Rickenmann, 1999; Bollschweiler et al., 2005) or on the assessment of threshold values for the triggering of events (Caine, 1980; Wilson and Wieczorek, 1995; Blijenberg, 1998; Bovis and Jakob, 1999; Huggel et al., 
2002; Cannon et al., 2003). In a similar way, the magnitude and frequency of debris flows have repeatedly been reconstructed or the moment of past activity assessed by means of aerial photographs, and/or field investigations (Hungr et al., 1984; Van Steijn, 1996; Zimmermann et al., 1997, Corominas and Moya, 1999) as well as with lichenometry (Innes, 1983, 1985; Jonasson et al., 1991; Winchester and Harrison, 1994; Helsen et al., 2002).

Previous debris-flow studies using dendrogeomorphological methods primarily focused on the dating of individual events or deposits (Stefanini and Ribolini, 2003), on the reconstruction of magnitude and/or frequencies (Strunk, 1997; Baumann and Kaiser, 1999, May and Gresswell, 2004; Stoffel et al., 2005a, 2006) or on a comparison of debris-flow data with flooding in neighboring rivers (Stoffel et al., 2003).

While these tree-ring studies furnished valuable data on recurrence intervals of debris flows, they widely neglected the behavior of past debris-flow activity and the analysis of areas affected during particular events.

It is therefore the purpose of this study to date growth disturbances in heavily disturbed Larix decidua Mill. and Picea abies (L.) Karst. trees on a debris-flow cone in the Swiss Alps so as (i) to reconstruct periods with debris-flow activity in currently abandoned channels and (ii) to assess the spatial extent of individual events. We report results obtained from detailed geomorphic mapping (1:1000) and dendrogeomorphological analysis of 401 trees growing on the Bruchji cone near Blatten b. Naters (Valais, Switzerland). Data allowed spatiotemporal reconstruction of 40 debris flow events between A.D. 1867 and 2005 as well as the determination of past debris-flow activity in eleven channels being currently abandoned.

\section{Study site}

The study was conducted on the cone of the Bruchji torrent, located north-northeast of the village of Blatten b. Naters (Valais, Swiss Alps, $46^{\circ} 22^{\prime}$ N/7 $7^{\circ} 59^{\prime}$ E; Fig. 1). The cone extends from 1380 to $1520 \mathrm{~m}$ a.s.l. and is covered with an open forest built of Norway spruce (Picea abies (L.) Karst.) and European larch (Larix decidua Mill.). Slope gradients on the cone average $13^{\circ}$

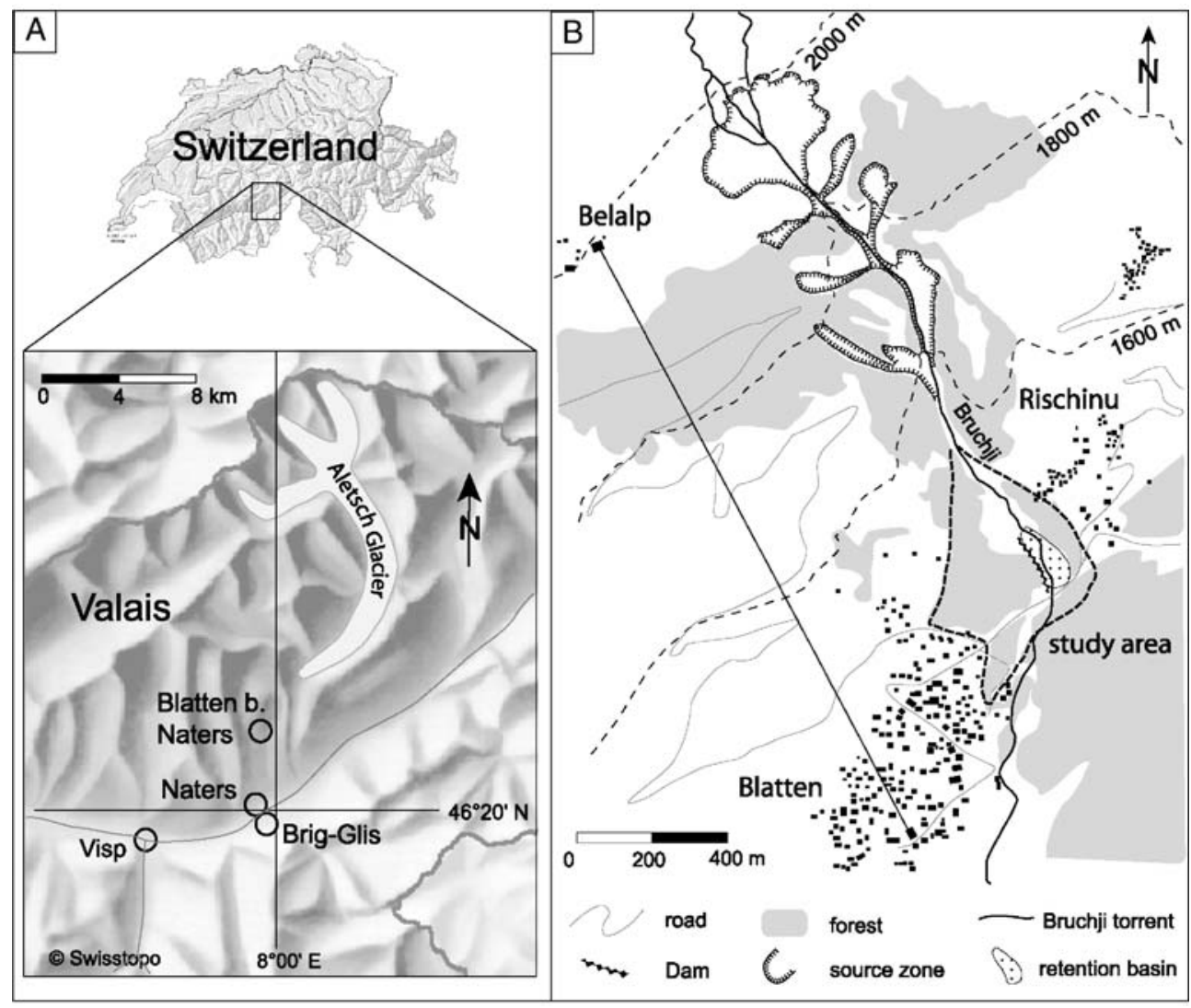

Fig. 1. (A) The Bruchji torrent is located in the Swiss Alps near the village of Blatten b. Naters (Canton of Valais). (B) Sketch map of the Bruchji torrent with its departure zone, the study site and the protection measures built in the late 1970s. 
and anthropogenic activity is most obvious in its lowermost part, where the cone surface has been strongly reshaped through the construction of holiday homes.

Debris flows are commonly triggered from an unstable zone located between 1600 and $2000 \mathrm{~m}$ a.s.l. (Fig. 1). Here, the retreat of the Aletsch Glacier following the last glaciation (i.e. Würm; Hantke, 1980) caused major slope instabilities, disintegrating huge amounts of gneissic bedrock. This material belongs to the crystalline Aar massif (Labhart, 2004) and is easily mobilized during heavy rainfall (Jossen, 2000). Once released, debris flows pass through a short (length: $100 \mathrm{~m}$ ) and deeply incised gorge before they reach a well-developed cone (13 ha).

Archival data on past events in the Bruchji torrent are scarce. Debris-flow activity is noted for the period
1905-1907 (Jossen, 2000) and for four events after 1987. In between, there is a large gap and information does not exist.

In order to prevent future damage to infrastructure caused by debris flows, protection measures were undertaken in the late 1970s (debris retention basin, deflection dam; see Fig. 1) and the banks of the main channel were reinforced in order to prevent debris flows from reaching the village of Blatten (Imhof, pers. comm.). Nonetheless, several debris-flow surges caused significant overbank sedimentation on 4 July 2001, which is the reason why the existing retention basin and the deflection dam were enlarged. Downstream of the retention basin, the channel was incised by approximately 1 m (Bollschweiler, 2003; Ehmisch, 2005).

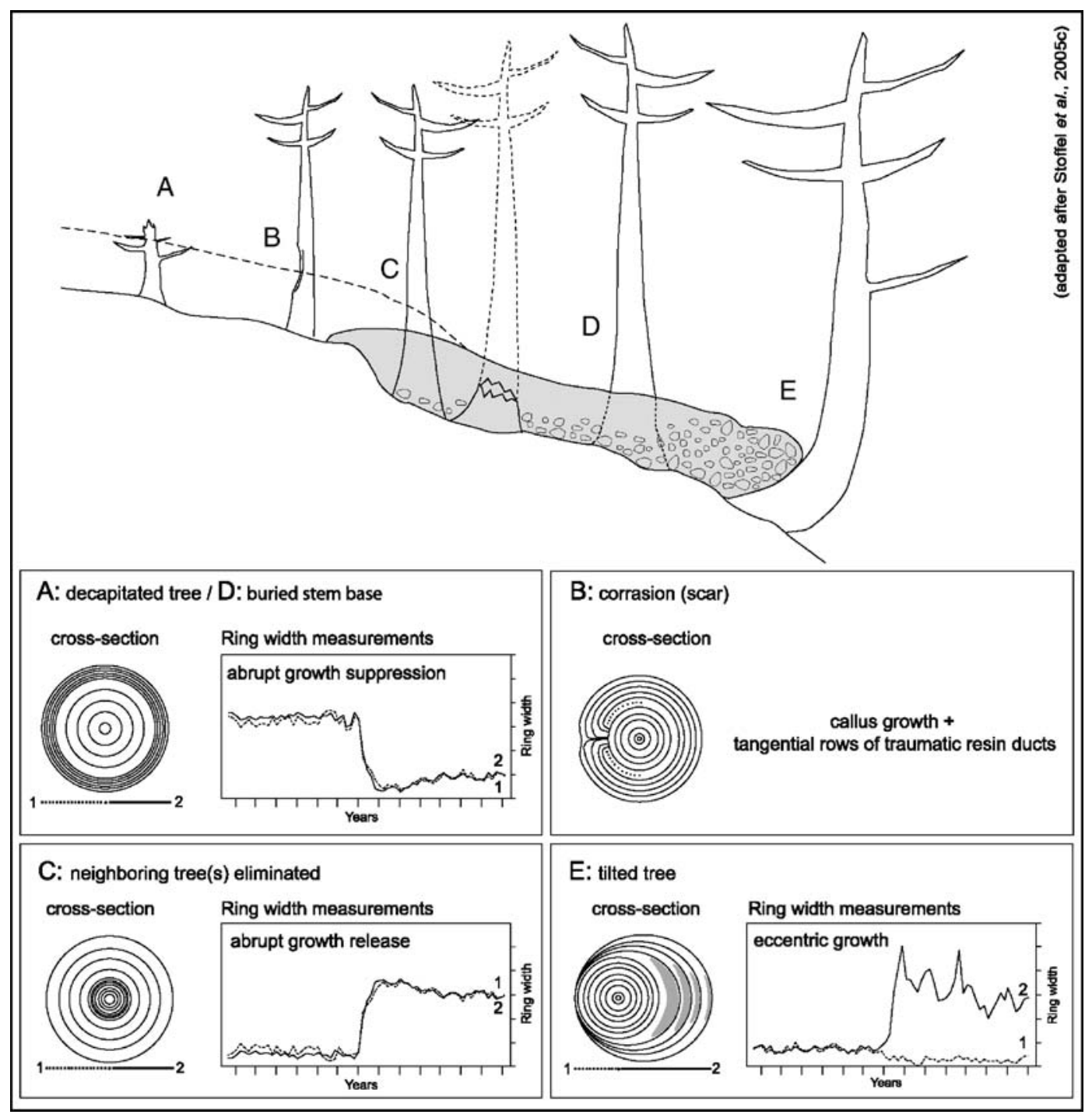

Fig. 2. Growth reactions of trees affected by debris flows. 


\section{Methods and material}

\subsection{Geomorphic mapping}

In a first analytical step, all forms and deposits related to former debris-flow activity (i.e. lobes, levees or abandoned channels) were mapped in a scale of 1:1000. Due to the presence of forest on the cone, GPS devices could not be used. Thus the map was based on detailed field measurements using compass, tape measure and inclinometer.

\subsection{Sampling strategy and dating of past events}

Geomorphic processes may influence trees in various ways (see Alestalo, 1971; Shroder, 1978, 1980; Schweingruber, 2001). The impact of rocks and boulders or abrasion processes may cause scars to the stem surface or even decapitate trees. Unilateral pressure of flowing material can result in a tilting of the stem. Finally, material may bury the stem base when deposited. Affected conifer trees react to these impacts with callus tissue, tangential rows of traumatic resin ducts (Stoffel et al., 2005b,c; Perret et al., 2006), the formation of reaction wood (Giardino et al., 1984; Braam et al., 1987; Fantucci and Sorriso-Valvo, 1999; Stefanini, 2004; Stoffel et al., 2005a) or with an abrupt growth suppression or release (Strunk, 1997). Fig. 2 gives an overview of the different impacts of debris flows on trees and their reactions to the disturbances.

Within this study, 802 increment cores from $401 P$. abies and $L$. decidua trees growing on the debris-flow cone were sampled. These species were chosen because they are excellent recorders of past events and because they have comparably low numbers of missing or false tree rings (see Schweingruber, 1978, 1996; Schweingruber et al., 2006). Only trees obviously influenced by former events (i.e. tilted, injured or decapitated trees, buried stem base) were cored. Two cores were normally extracted per tree with increment borers, one on the side of the impact, another one on the opposite side of the trunk. Sampling height was chosen according to the morphology of the stem: Injured or tilted trees were sampled at the height of the disturbance; cores from trees with buried stem base or from decapitated trees were, in contrast, extracted next to the stem base so as to preserve as much tree-ring information as possible. For each tree sampled, additional data were gathered including (i) description of the disturbance and morphology, (ii) determination of its position within the deposits, (iii) tree diameter at breast height, (iv) position of the cores sampled (i.e. upslope, downslope, other), (v) information on neighboring trees. The position of each tree sampled was precisely marked on the geomorphic map.

In addition to the disturbed trees sampled on the cone, we selected undisturbed $L$. decidua and $P$. abies trees from a nearby forest stand showing no signs of debris-flow activity or any other geomorphic process. Reference chronologies were built with 30 trees per species so as to obtain information on "normal" growth conditions at the location (i.e. climate, insect outbreaks; Cook and Kairiukstis, 1990).

Samples were analyzed using the standard methods described by Bräker (2002). Individual working steps included surface preparation, counting of tree rings as well as measuring of ring widths using a digital LINTAB positioning table and TSAP 3.0 software (Time Series Analysis and Presentation; Rinntech, 2006). Increment curves of the disturbed trees were then crossdated with the reference chronology in order to correct faulty tree-ring series derived from disturbed samples (e.g., false or missing rings; Schweingruber, 1996). Thereafter, samples were analyzed visually and tree rings showing tangential rows of traumatic resin ducts (TRD), the onset of compression wood or callus tissue were noted on skeleton plots (Schweingruber et al., 1990), before the growth curves of the disturbed trees were compared with the reference chronology of the corresponding tree species in order to determine initiation of abrupt growth suppression or release.

Based on the age of the selected trees (i.e. number of tree rings available on the increment core at breast height), we assessed the approximate age structure of the forest stand on the Bruchji cone.

\subsection{Reconstruction of past channel activity and spatial patterns of former events}

The position of all trees with growth reactions in the same event year was marked on the geomorphic map. This representation of trees affected during individual events allowed (i) reconstruction of the extent of events on the cone, (ii) identification and interpretation of spatial patterns of past events as well as (iii) an assessment of activity in currently abandoned channels.

\section{Results}

\subsection{Geomorphic map}

Mapping of the entire debris-flow cone (13 ha) in a scale of 1:1000 allowed identification of 164 debrisflow lobes and 53 segments of debris-flow levees. 
However, none of the channels identified on the cone is deeply incised and the lobate deposits are normally only poorly developed with smooth surfaces. Fig. 3 shows all forms mapped and the position of the trees sampled.
Most deposits are present west of the currently active channel. On its upper part, the cone is relatively narrow and only a small number of geomorphic forms can be identified here, primarily levees interspersed with a few

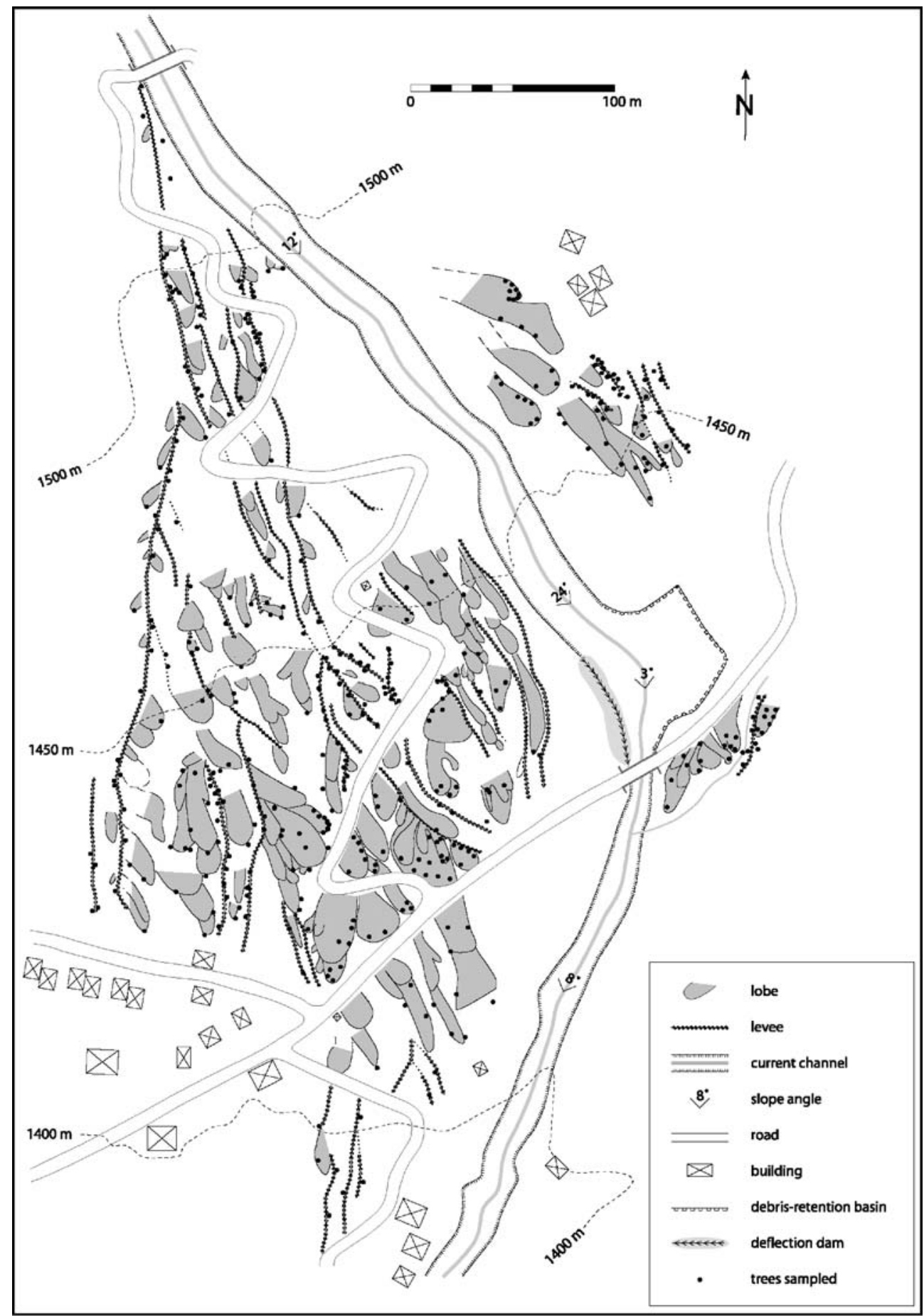

Fig. 3. Detailed geomorphic map (original scale: 1:1000) of the Bruchji cone representing all forms related to past debris-flow activity (levees, lobes, channels) and the position of all trees sampled. 
lobes. The biggest deposits are located in the central part of the cone, where a large number of lobes is present. It is also in this area where a large quantity of trees has been sampled. The lower part of the cone has, in contrast, been heavily reshaped by human activity. As a consequence, only a limited number of forms can be identified here and the number of trees sampled was comparably low.

\subsection{Age structure of the stand}

Data on the pith age at breast height indicate that the 401 L. decidua and P. abies trees on the Bruchji cone are, on average, 91 years old (STDEV: 32 years). While the oldest tree sampled for analysis attained sampling height in A.D. 1791, the youngest sample only reached breast height in 1987. As can be seen from Fig. 4, the sectors to the east of the current channel contain the youngest trees. Above the debris-retention basin, trees reach an average

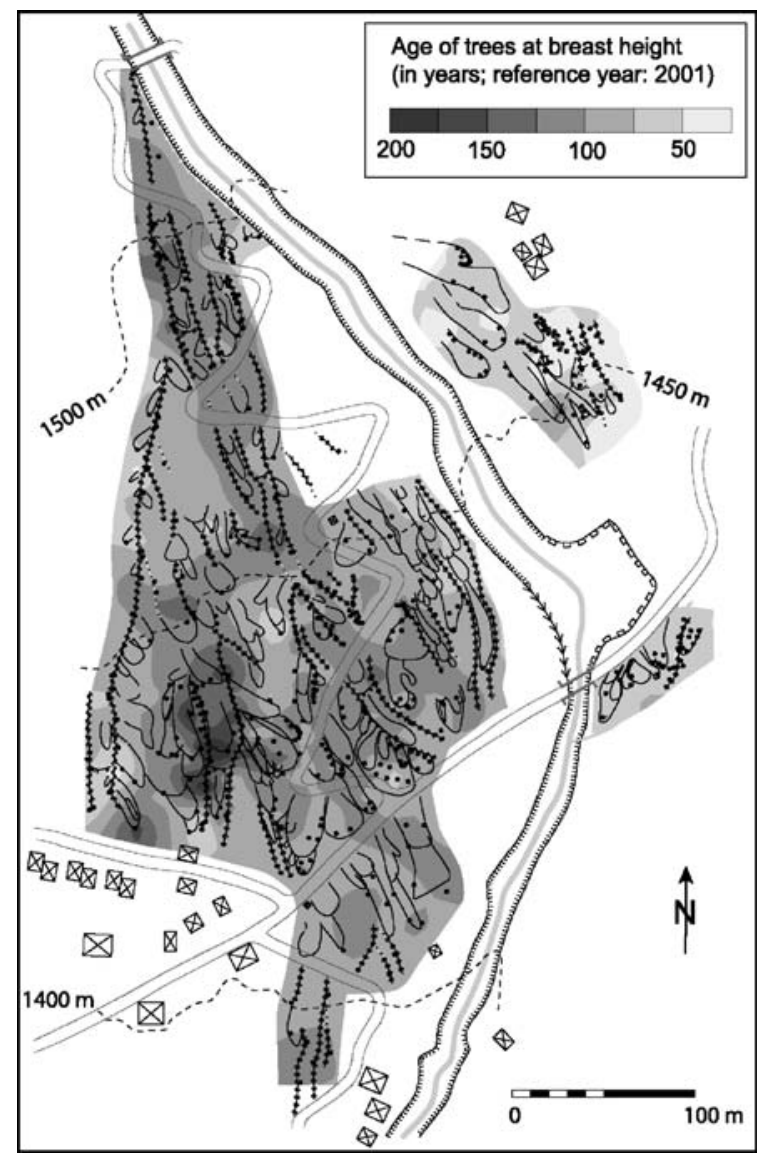

Fig. 4. Age structure of the forest stand on the Bruchji cone. The oldest trees are located in the western part of the cone whereas the trees in the eastern sectors are rarely older than 60 years. The oldest tree reached breast height in A.D. 1791.
Table 1

Different growth disturbances (GD) assessed in the 802 Larix decidua Mill. and Picea abies (L.) Karst. samples

\begin{tabular}{llc}
\hline Type of reaction & Number & $\%$ \\
\hline Tangential rows of traumatic resin ducts & 346 & 36 \\
Tangential rows of traumatic resin ducts + onset of & 172 & 18 \\
$\quad$ reaction wood & & \\
Onset of reaction wood & 165 & 17 \\
Abrupt growth change (suppression or release) & 122 & 13 \\
Tangential rows of traumatic resin ducts + abrupt & 117 & 12 \\
$\quad$ growth change & 38 & \\
Injury & & \\
& 960 & 100 \\
Total & & \\
\hline
\end{tabular}

of 51 years, whereas 63 tree rings were counted in those trees located below the basin. In contrast, the oldest trees can be found in the western part of the cone, where they locally reach an average of 150 years. Data also indicate that the area east of the active channel was apparently not colonized until the 1930s.

\subsection{Growth disturbances and minimum frequency of past debris-flow events}

In total, 960 growth disturbances (GD) were assessed in the 802 samples. Table 1 gives an overview on the different GD identified. Six different categories of GD have been defined. In the samples, we either identified single reactions in the form of tangential rows of traumatic resin ducts (TRD), abrupt growth changes (suppression or release), the onset of reaction wood or injuries. In addition, multiple reactions occurring simultaneously in a tree after disturbance (i.e. resin ducts and growth changes or resin ducts and reaction wood) were noted separately. Most frequently, GD were identified via the presence of TRD, occurring in $36 \%$ of all cases. The onset of reaction wood totaled $17 \%$ of all GD, whereas the combination of TRD and abrupt growth changes occurred in $12 \%$. Abrupt growth changes without TRD were recognizable in $13 \%$. In contrast, injuries could only rarely be assessed (4\%). Fig. 5 gives two examples of GD leading to the reconstruction of event years. While Fig. 5A illustrates a distinctive growth suppression in 1960 following an event in 1959, Fig. 5B shows the growth curves of a tree with eccentric growth and reaction wood as a result of tilting of the stem in 1927.

Overall, the identification of the 960 GD allowed reconstruction of 40 event years between 1867 and 2005 . Fig. 6A indicates the seven events known from archival data (i.e. 1907, 1987, 1990, 1994, 1995, 1996 and 2001), whereas Fig. 6B shows the 40 event years reconstructed in this study with dendrogeomorphological methods. Three 

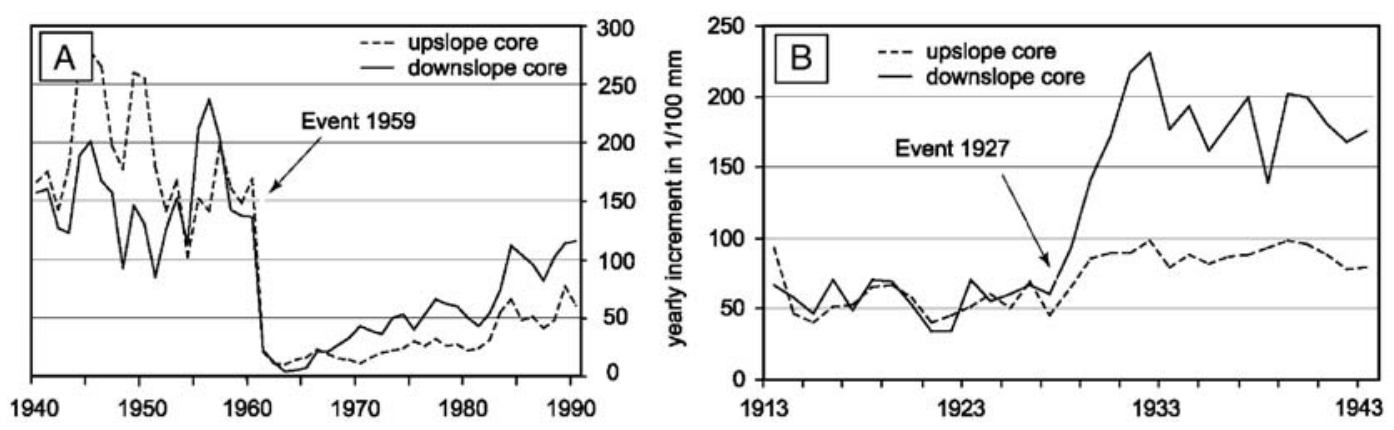

Fig. 5. Growth curves of trees affected during past events. (A) The increment curves of this tree show an abrupt growth suppression as a reaction to burying by debris-flow material in 1959. (B) As a reaction to the tilting by an event in 1927, this tree started to form reaction wood in the downslope core in the year following the disturbance.

of the seven documented event years $(1996,1994$ and 1907) could be identified in the tree-ring series as well. In contrast, the event years 1987, 1990 and 1995 could not be reconstructed with dendrogeomorphological methods. Since the event of 2001 occurred during the fieldwork for this study, no GD could be assessed in the tree rings. In addition to the events known from archives, 37 new event years were identified.

\subsection{Reconstruction of formerly active channels}

The localization of the trees with GD in a particular year on the geomorphic map allowed assessment of spatial patterns and activity in currently abandoned channels. The visualization of the event years on the map yielded data on eleven formerly active channels and their activity during the past decades. Fig. 7 shows the location of the different channels on the map. For some of the channels, only short fragments of their lateral levees can be identified, e.g. for channels 4 or 10 . Here, only some $30 \mathrm{~m}$ of the levees are still recognizable in the field, whereas signs of other channels can be followed over a considerable distance (up to $300 \mathrm{~m}$ ) on the cone. Table 2 provides data on past debris flows in the eleven channels and clearly indicates that mainly channels $1,2,3$ and 5 have been repeatedly active
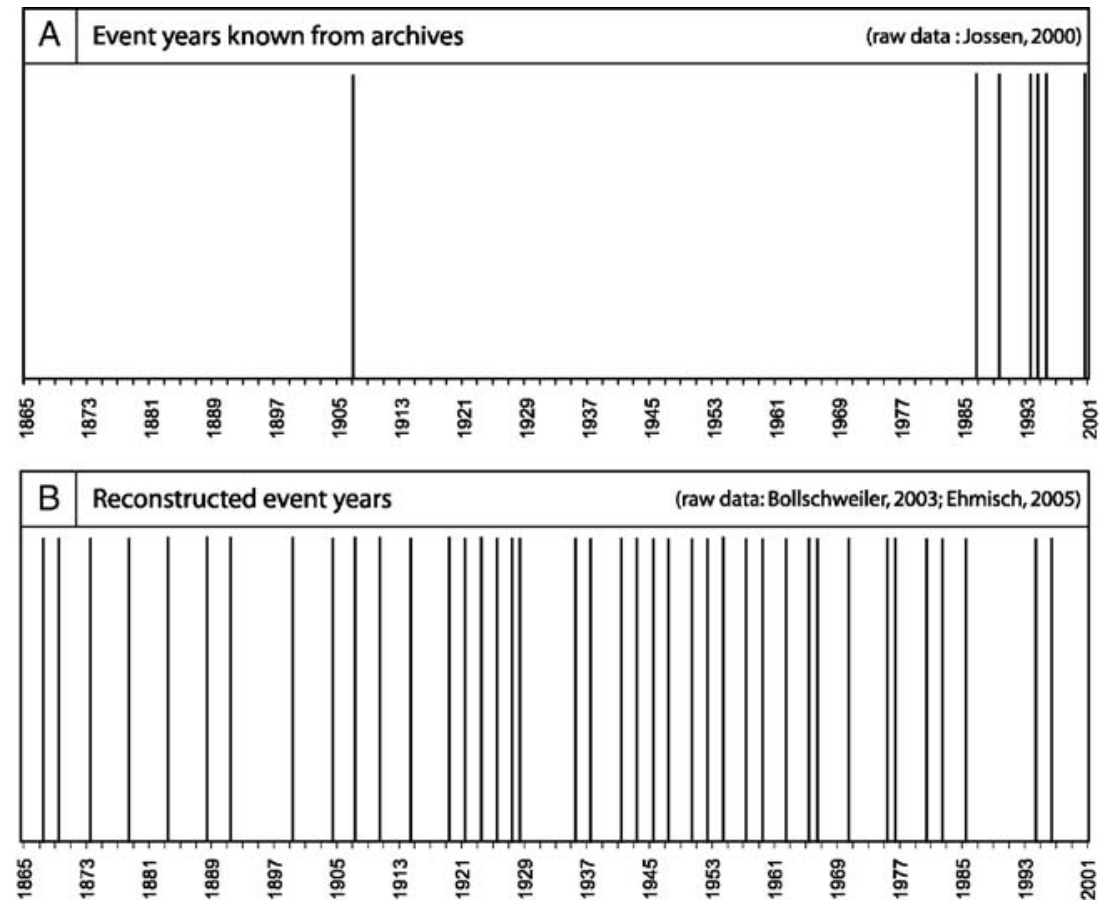

Fig. 6. Reconstructed frequency of debris flows in the Bruchji torrent. (A) Archival data report seven events for the 20th century, with six events concentrated to the last 20 years. (B) Tree-ring data, in contrast, produced data on 40 events between A.D. 1867 and 2005. 
during past events. The most recent events in channels 1 and 5 were dated to 1978, whereas activity in channels 2 and 3 only ceased in 1982. In contrast, only very limited activity could be reconstructed for the other channels, with only one event (1957) dated for channel 9. As a result of the protection measures (retention basin, channel reinforcement) initiated in the 1970s, channel activity in the western part of the cone was interrupted. Nevertheless, the event in 1982 reached channel 3 and affected trees in the western part of the cone.

\subsection{Spatial patterns of former events}

The position of all trees showing growth disturbances (GD) in a specific event year was then used to assess spatial patterns of the 40 events reconstructed on the

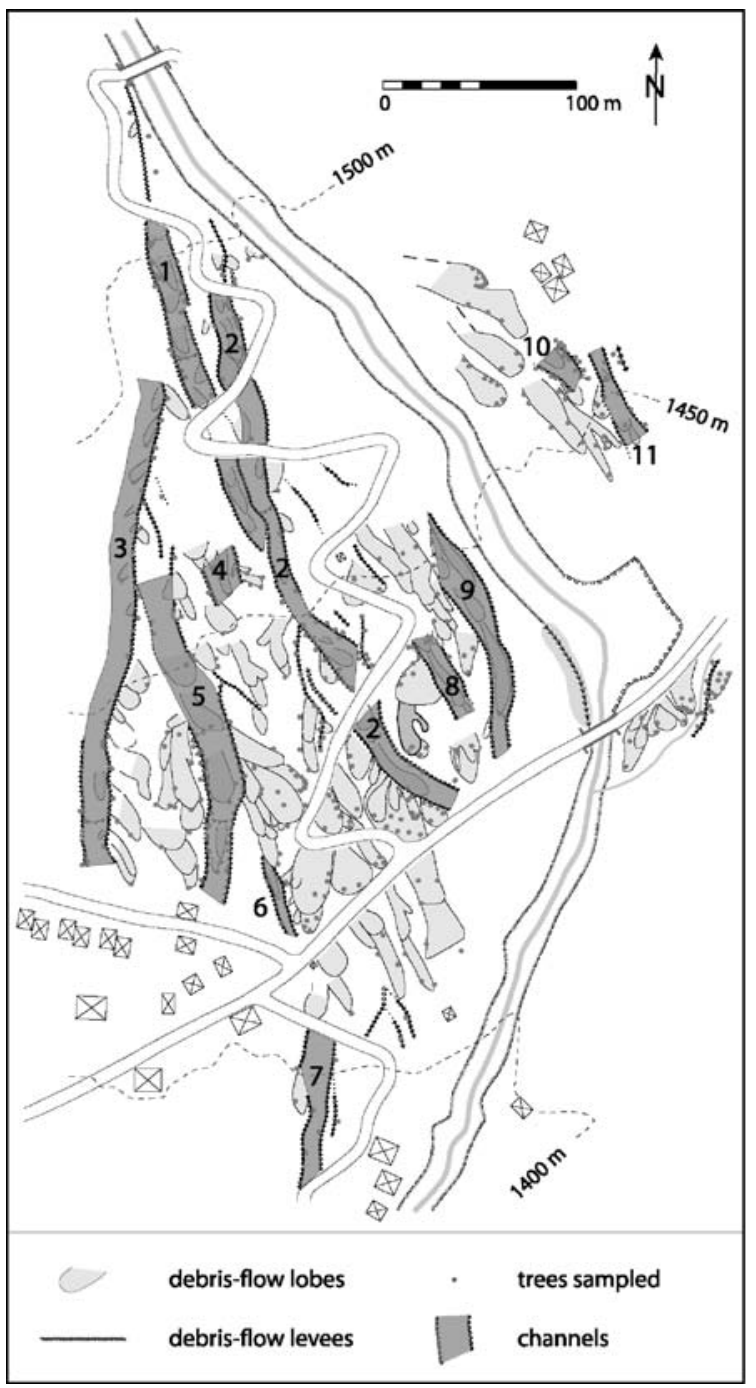

Fig. 7. Localization of the eleven channels identified on the cone.
Table 2

Debris-flow channels and periods of activity: the first and the last event reconstructed for individual channels are noted as well as the total number of events reconstructed between A.D. 1867 and 2005

\begin{tabular}{llll}
\hline Channel & First event & Last event & Number of events \\
\hline 1 & 1867 & 1978 & 18 \\
2 & 1867 & 1982 & 25 \\
3 & 1869 & 1982 & 10 \\
4 & 1952 & 1962 & 3 \\
5 & 1869 & 1978 & 20 \\
6 & 1907 & 1947 & 5 \\
7 & 1891 & 1954 & 3 \\
8 & 1904 & 1962 & 6 \\
9 & 1957 & 1957 & 1 \\
10 & 1952 & 1985 & 8 \\
11 & 1952 & 1980 & 3 \\
\hline
\end{tabular}

For the location of the individual channels see Fig. 7.

cone for the period A.D. 1867-2005. Based on the spatial distribution of trees disturbed during particular events, five different patterns of spatial activity were distinguished. The five patterns are described below and illustrated with one characteristic example each:

\subsubsection{Pattern A: debris flows affecting the western part of the cone}

Events affecting the western part of the cone are mainly characterized by activity in channel 3 with debris-flow material leaving the currently active channel directly at the apex of the cone. On its way down the cone, breakouts of surges from channel 3 can occasionally be observed at about $1470 \mathrm{~m}$ a.s.l. with a subsequent activation of channel 5 . The spatial distribution of trees affected during particular events also indicates that debris flows even continued from channel 5 to the lowermost part of the cone using channels 6 and 7. Fig. 8A illustrates the spatial behavior of debris-flow activity on the cone during an event in 1907. In this example no trees were influenced in the lowermost part of channel 3.

Events affecting the western part of the cone (pattern A) were most frequently reconstructed on the cone with a total of 18 events. Two of them (i.e. 1881, 1937) apparently left channel 3 near the apex of the cone and five others (i.e. 1869, 1891, 1921, 1925, and 1976) passed through channel 5 but not through channel 1. There is also evidence from the tree-ring records and geomorphic mapping that the remaining eleven events (i.e. 1873, 1878, 1883, 1899, 1907, 1910, 1914, 1928, 1947, 1970 and 1978) did apparently not use channels 1 and 5. From the data, we assume that past debris flows preferably followed channels 1 and 5 over the entire period of reconstructed debris-flow activity, with events dated for the first time in 1869 and in 1978 for the last time. 
4.5.2. Pattern B: debris flows affecting the central part of the cone

Debris flows affecting the central part of the cone are mainly characterized by activity in channels 1 and 2 . Here, debris-flow material left the currently used channel at the apex of the cone as well. The spatial distribution of trees affected during particular events also indicates that debris flows even continued from channel 2 to the lowermost part of the cone. In contrast, the early events in the central part of the cone could only be reconstructed in the uppermost segments of channels 1 and 2. Fig. 8B illustrates the spatial behavior of debris-flow activity on the cone during an event in 1919 with GD also identified in the lowermost part of the cone. In total, pattern B could be reconstructed for four events (1867, 1919, 1923 and 1927).

\subsubsection{Pattern C: debris flows affecting the eastern part of the cone}

Debris flows affecting the eastern part of the cone are mainly characterized by activity in the currently used channel and breakouts of surges at different locations. Most commonly, material left the channel at about $1470 \mathrm{~m}$ a.s.l. and affected trees east of the channel. In addition, trees below the debris-retention basin were

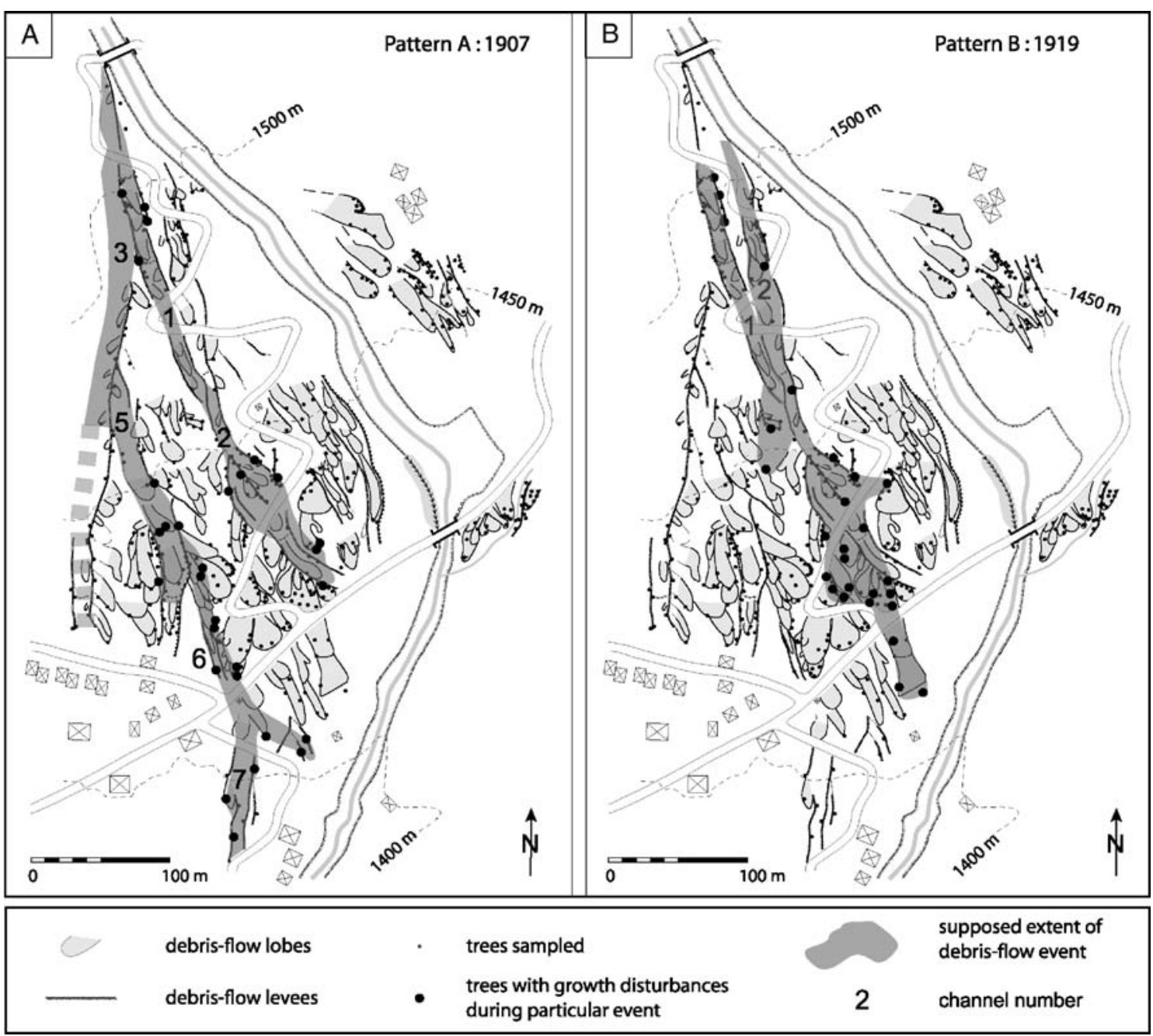

Fig. 8. Spatial patterns of past debris-flow events: (A) Debris flows affecting the western part of the cone and channel 3 as exemplified with an event in 1907 (pattern A). In some cases, surges even reached the lowermost parts of the cone following channels 5, 6 and 7. (B) Debris flows restricted to the central part of cone occurred e.g., in 1919 using channels 1 and 2 (pattern B). (C) Debris flows only influencing the eastern part of the cone illustrated with the event of 1980 (pattern C). (D) In pattern D, surges used different channels at the apex of the cone and, thus, affected both the western (channel 3) and the eastern part of the cone. The debris flow of 1954 is a typical event showing this behavior. (E) During some events, trees located over large areas of the cone showed growth disturbances caused by debris-flow activity (pattern E). As can be seen from the distribution of trees disturbed by the 1962 event, almost the entire cone was affected by the surges. 


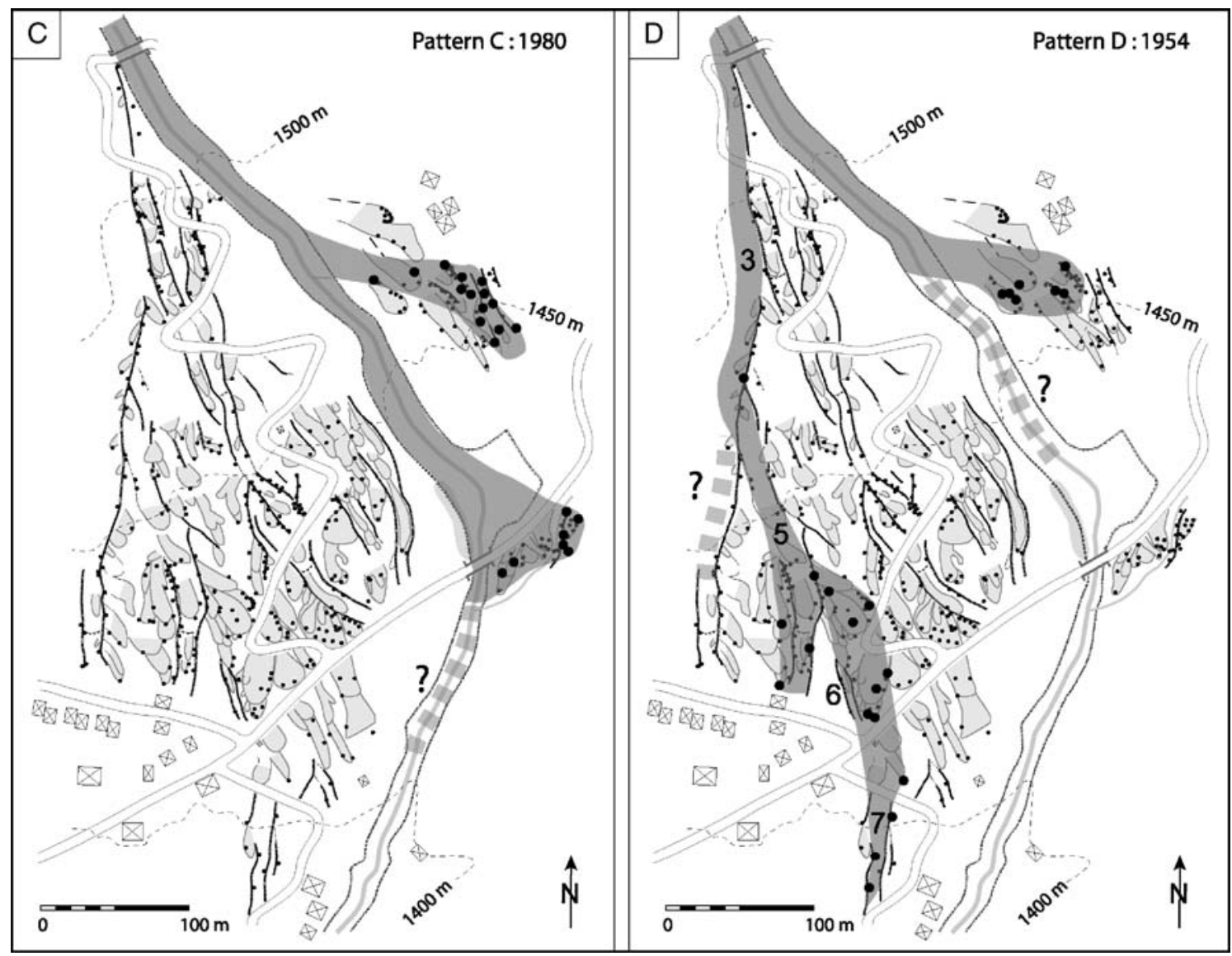

Fig. 8 (continued).

influenced by debris-flow activity of this pattern. Spatial distribution of trees affected during certain events also indicates that debris flows left the currently active channel between 1450 and $1500 \mathrm{~m}$ a.s.l. towards the west, causing growth disturbances to trees near channels 8 and 9. Fig. 8C illustrates the spatial extent of debrisflow activity during an event in 1980. In this example, no trees were influenced west of the currently active channel. Pattern C could be reconstructed for eight events, with three events only affecting trees east of the channel (i.e. 1980, 1985 and 1996) and five events affecting trees on both sides (i.e. 1945, 1950, 1957, 1965 and 1994). While no events could be reconstructed for the eastern part of the cone before 1945, all events after 1982 apparently caused GD to trees growing in this part of the cone.

\subsubsection{Pattern D: debris flows affecting the eastern and the western part of the cone}

Debris flows affecting the eastern and western parts of the cone are mainly characterized by activity in channel 3 and in the currently active channel. In the western part, breakouts from channel 3 apparently occurred at about $1470 \mathrm{~m}$ a.s.l. following channel 5 and sometimes even continuing to the lowermost part of the cone using channels 6 and 7. In addition, material leaving the currently used channel at the apex of the cone affected channels 1 and 2. The spatial distribution of trees disturbed during particular events also indicates that debris flows continued to the lowermost part of channels 1 and 2 during some events. In the eastern part of the cone, the currently active channel has seen breakouts to the east at about $1470 \mathrm{~m}$ a.s.l. and below the debrisretention basin. Trees standing west of the currently active channel were also injured during some events as a result of breakouts between 1450 and $1500 \mathrm{~m}$ a.s.l. Fig. $8 \mathrm{D}$ illustrates the spatial extent of debris-flow activity on the cone during an event in 1954. In this example, affected trees indicate activity in channels 3 and 5 down to the lowermost part of the cone. Surges also left the currently active channel at about 1480 masl, thus disturbing trees in the eastern part of the cone. In total, five events (1952, 1954, 1966, 1975 and 1982) could be assessed for pattern D. 


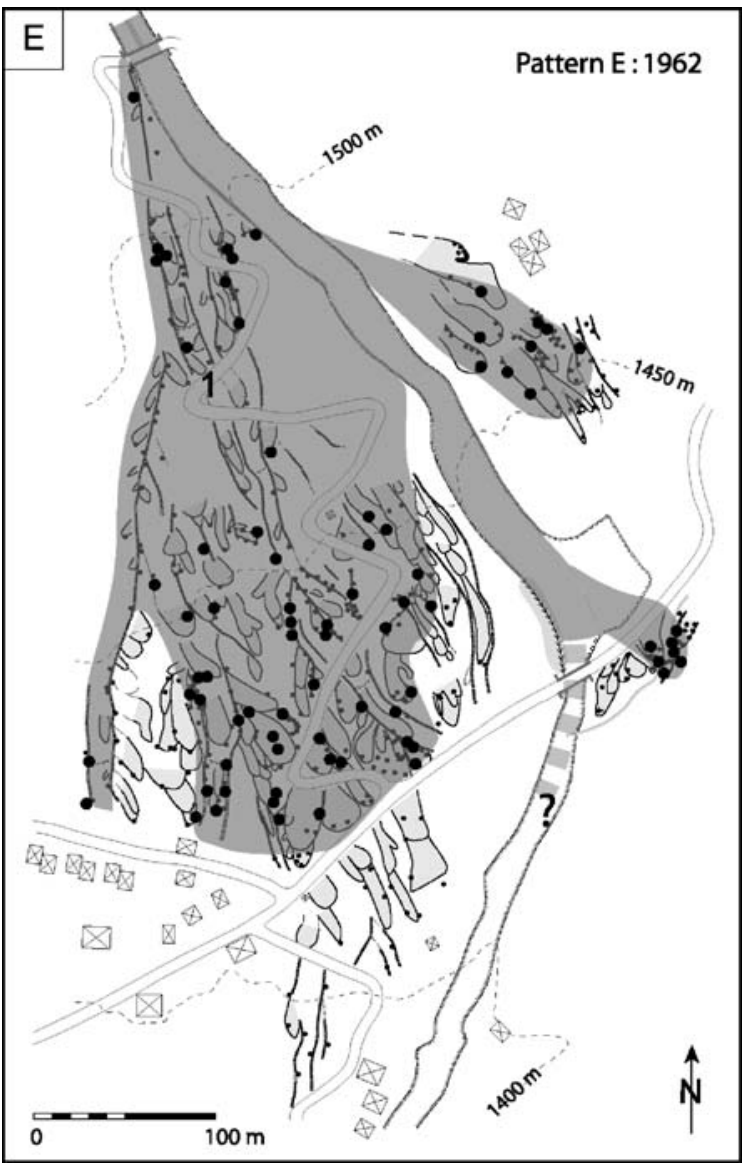

Fig. 8 (continued).

4.5.5. Pattern E: debris flows affecting the entire cone

During debris-flow events of pattern E, disturbed trees can be identified in (almost) all parts of the cone and signs are not limited to individual channels. Fig. 8E illustrates the spatial behavior of debris-flow activity on the cone during an event in 1962. In this example, no trees were influenced in the lowermost part of the cone. Pattern E could be reconstructed for five events (1935, 1941, 1943, 1959 and 1962).

\section{Discussion}

In this study, a coupling of detailed geomorphic mapping and dendrogeomorphological analysis has been used to assess the frequency and spatial extent of debris-flow events on the Bruchji torrent (Blatten $b$. Naters, Valais, Swiss Alps) for the last 140 years. The analysis produced data on 40 events between A.D. 1867 and 2005 and allowed reconstruction of past activity in eleven channels that are currently abandoned. In addition, the large amount of tree-ring data and the results from the geomorphic mapping enabled distinction of five different patterns of spatial activity of former debris-flow events.

The dendrogeomorphological reconstruction of debris-flow events at the Bruchji torrent was, however, mainly limited by the relatively young age of the trees. Even though we identified some trees with more than 200 tree rings in the western part of the cone, the average age of the trees sampled was only 91 years. In the eastern part of the cone, most trees were even younger and germinated only about 60 years ago. Furthermore, small debris-flow surges may have remained in the incised channels and did not necessarily cause growth disturbances (GD) to any of the investigated trees. For example, the events of 1987, 1990 and 1995, known from archives could not be identified in the tree-ring series. Since these events left the currently active channel only in non-forested sectors, it was not possible to reconstruct them with means of tree-ring analysis. As a result, the number of reconstructed events for the Bruchji cone has to be seen as a minimum frequency of past debris-flow activity in this torrent. However, the reliability of the reconstruction can be considered high because of the large number of trees showing GD for individual event years. Similarly the spatial extent of the events on the debris-flow cone appears to be very reliable for at least the 20th century. In contrast, we were not always able to delimit the extent of events in the lowermost parts of the cone as human activity considerably reshaped the cone surface here. On a regional level, the frequency of debris-flow events at Bruchji torrent is comparable to that reconstructed for the Ritigraben torrent (Stoffel and Beniston, 2006). Other geomorphic events, such as snow avalanches or rockfall activity have never been witnessed at the study site and have therefore no influence on tree growth.

The age structure of the stand has been approximated by counting the number of tree rings present on the increment cores sampled at breast height. However, we are aware that tree age at breast height does neither provide germination nor inception dates (Gutsell and Johnson, 2002). In addition, the pith as well as the innermost rings of some trees was rotten, making it impossible to assess the real age of the tree. Nonetheless, we are convinced that the approach furnishes valuable data on the age structure of the stand with reasonable precision.

In total, 960 GD were assessed in the 802 Larix decidua Mill. and Picea abies (L.) Karst. samples. Tangential rows of traumatic resin ducts (TRD) represent $36 \%$ of all GD, while injuries only account for $4 \%$ of the reconstructed GD. This scarcity of injuries 
as compared to other signs of past activity may be explained through the sampling strategy. We used increment cores for the sampling instead of crosssections since the forest stand at the study site has a protective function against debris flows. The thick bark of $L$. decidua and $P$. abies trees efficiently blurs evidence of past events, as it grows abundantly and sporadically scales off its outermost layers (peeling; Stoffel and Perret, 2006). Therefore, injuries are easily overgrown and no longer visible on the stem surface. Nonetheless, we are confident that these overgrown signs of past events were accurately dated via the presence of TRD formed next to the injuries.

The spatio-temporal representation of tree-ring data on the geomorphic map allowed assessment of activity in eleven abandoned channels as well as on the extent of past events on the cone. While reconstructions suggest very frequent debris-flow activity in channels 1,2, 3 and 5, events did apparently not or only exceptionally affect other channels during the last 140 years. We believe that the scarcity of events in the channels on the eastern part of the cone is rather the result of the limited age of trees than of an absence of events in this sector in the late 19th or early 20 th century. As suggested by the age distribution of trees (see Fig. 4) and confirmed by an aerial photograph dated to 1936 (Fig. 9), the eastern part of the cone served as grazing land during the first decades of the 20th century. This explains why the forest could only develop over the last 60 years. It also seems that the demolition of two buildings by a debris-flow event in 1935 and the covering of the grazing lands with considerable amounts of material favored the abandonment of the cultivated

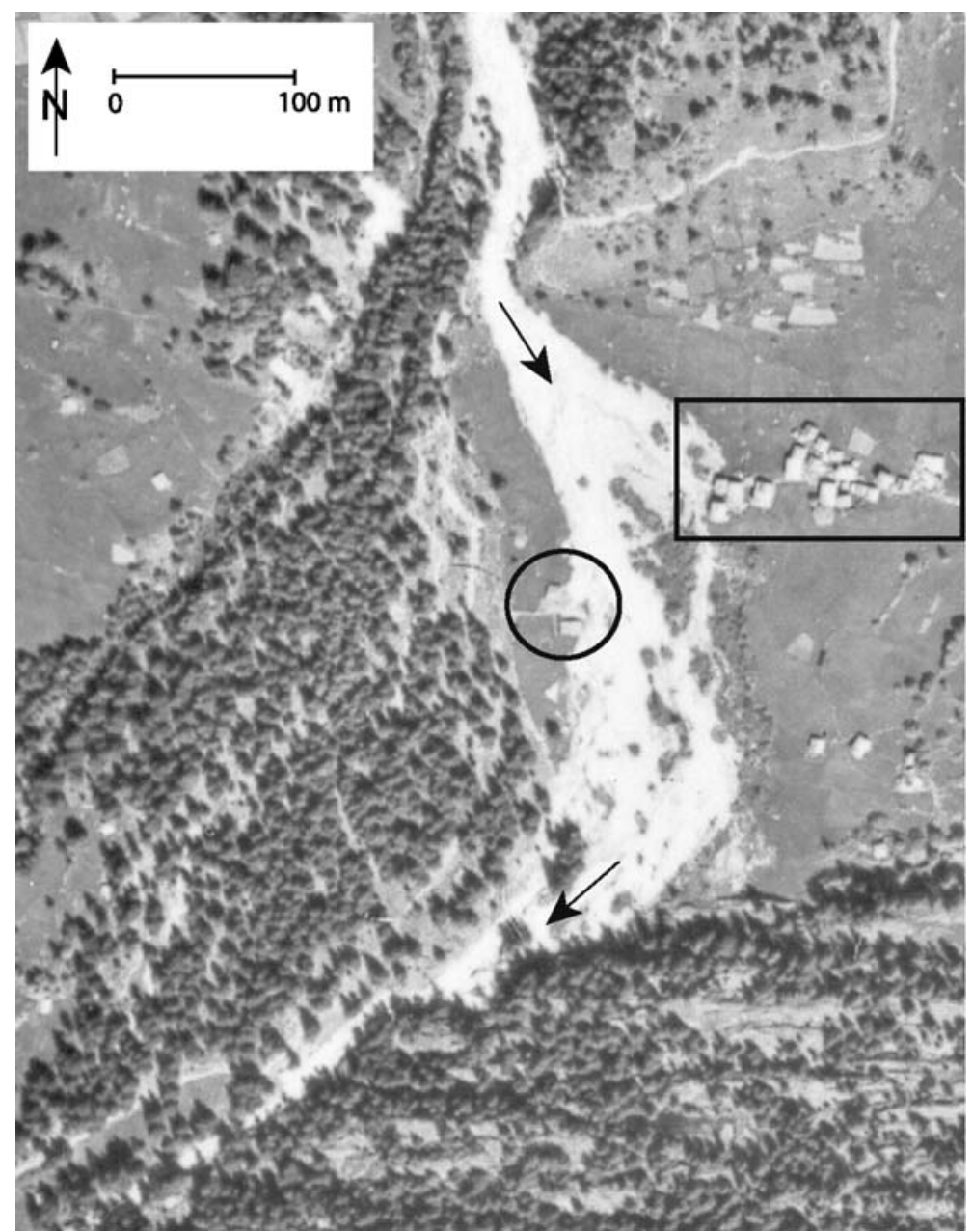

Fig. 9. Aerial photograph of the Bruchji cone taken in May 1936. Two buildings (circle) are located within the deposits and appear to have been severely affected by the debris-flow event reconstructed for 1935. Towards the northeast of the damaged building, houses of a small hamlet (rectangle) are found very close to the deposition zone of the 1935 event as well. Arrows indicate the flow direction of water in the torrent (aerial photograph reproduced with courtesy of swisstopo (BA068080)). 
lands and, hence, the establishment of the present forest stand.

Based on our data, we were also able to distinguish five spatial patterns for past debris-flow events. As a result of the age of trees sampled, events occurring before 1935 were limited to the western (pattern A) or the central part (pattern B) of the cone and GD cannot be identified in trees located elsewhere at the study site. Nonetheless, we believe that events affecting the eastern part of the cone must have been very unusual before 1935. Even though tree-ring data cannot be used here to underpin this assumption, we are confident that neither the small hamlet nor the two buildings located within the deposits of the 1935 event would have been constructed or the grazing land used (see Fig. 9) had there been frequent debris-flow activity in this part of the cone. Another aerial photograph taken in August 1940 confirms our assumption, as one of the houses had been removed. In contrast, events reconstructed for the period 1935-2005 did apparently more often affect the eastern (pattern C) or both the eastern and the western parts (pattern D) of the cone.

In the late 1970s, different protection measures have been undertaken so as to prevent debris-flow material from reaching the western part of the cone as well as the village of Blatten $b$. Naters. Therefore, the banks of the active debris-flow channel have been reinforced at the apex of the cone so as to prevent debris flows from leaving the currently active channel. In addition, a small retention basin has been constructed. Even though these protective measures aimed at eliminating debris-flow activity in the western part of the cone, we can see from reconstructed GD in the trees that at least the event of 1982 still reached channels 3 and 5 .

Based on our data, the areas affected during particular events, the scarcity of lobate deposits, the smooth cone surface and based on personal observation made during a series of debris-flow surges on July 4, 2001, we believe that a majority of the reconstructed events must have had a rather high water content and should be considered hyperconcentrated rather than "classical" debris flows. This is especially true for the events covering the entire cone (pattern E; e.g., 1962, 1941) but also for some of the other events that affected a large number of trees over a large area of the cone (e.g. 1982, 1966, 1952). The distribution of trees affected during particular events also corroborate our assumption on the repeated presence of hyperconcentrated flows on the cone. Due to the high water content and the limited amount of abrasive material and boulders, trees standing in the direction of the flow did not always show GD during a particular event year, even though we are confident that they must have been located within the area affected by the event. As a result, we assume that only those trees directly hit by rocks and boulders or suffering from abrasion by the finer fractions transported during the event were sufficiently affected to show GD, whereas those trees "only" influenced by the action of water or mud did not react upon the disturbance.

Finally, the geomorphic map shows that a large number of channels but only a limited number of lobes can be observed on the cone. Therefore, we suppose that only comparably little material was deposited on the cone during past events. This is in contrast to findings of Haeberli et al. (1991) suggesting that up to $80-90 \%$ of debris-flow material is generally deposited on cones. Due to the high amount of water present in many of the past events, it is also conceivable that material has been left on the cone but reworked or removed by subsequent surges. As a result, it was not possible within this study to date deposits on the cone with tree-ring analysis. In a similar way, the levees identified on the cone were normally not very well formed, as can be seen e.g., in the upper part of channel 5. For different events reconstructed in this channel, trees located outside the channel seem to have been affected by the event as well and show distinct growth reaction.

\section{Conclusion}

The combination of detailed geomorphic mapping and tree-ring analysis allowed reconstruction of eleven formerly active channels and the spatial occurrence of past debris flows. Based on the data, five different patterns of spatio-temporal activity of past debris flows could be identified on the forested cone of the Bruchji torrent. While older events normally affected trees in the western part of the cone, the flow regime apparently changed in the mid-1930s towards the eastern part of the cone. As a result of different protection measures realized in the late 1970s, channels in the western part of the cone are no longer active today. In addition, tree-ring based reconstructions also allowed identification of several events that affected the entire cone and caused growth disturbances to a large number of trees. Due to the limited number of deposits left on the cone, the spatial patterns of past events and the large number of trees affected during individual event, we believe that many of the reconstructed events would have been hyperconcentrated rather than debris flows.

The methods developed in this study can be readily transferred to any other alpine catchments and should therefore be used in similar environments for a better understanding of past and potential future debris-flow processes. 


\section{Acknowledgements}

The authors want to express their gratitude to Canton of Valais, the Swiss Federal Office for Water and Geology (grant number: BWG 804.3189.002.01.01) and the municipality of Naters (Valais) for financial support. We are grateful to Armin Imhof for archival data. We also address our thanks to Drs. Astrid Röpke and Holger W. Gärtner for all manners of assistance in the field and/or the laboratory. The authors also acknowledge Sebastian Feick, Sven Brinckmann, Nicole Gaillard and Heidi Ehmisch for assistance in the field. We want to address our special thanks to Dominique Schneuwly for his great assistance in the field and the lab as well as his helpful comments on an earlier version of the manuscript. Finally, we also thank Oliver Korup and an anonymous reviewer for helpful comments.

\section{References}

Alestalo, J., 1971. Dendrochronological interpretation of geomorphic processes. Fennia 105, 1-140.

Baumann, F., Kaiser, K.F., 1999. The Multetta debris fan, Eastern Swiss Alps: a 500-year debris flow chronology. Arct. Antarct. Alp. Res. 31 (2), 128-134.

Blijenberg, H., 1998. Rolling stones? Triggering and frequency of hillslope debris flows in the Bachelard valley, Southern French Alps. Ph.D. Dissertation. Faculteit Ruimtelijke Wetenschappen, Universiteit Utrecht.

Bollschweiler, M. 2003. Frequenzanalyse von Murgangereignissen anhand dendrogeomorphologischer Untersuchungen. Murkegel Bruchji, Blatten b. Naters, Wallis, Schweiz. Diploma thesis. University of Fribourg.

Bollschweiler, M., Stoffel, M., Schneuwly, D., 2005. Veränderungen der Murrinnen im Täschgufer seit 1936. Wasser Energie Luft 97 (7-8), 218-223.

Bovis, M.J., Jakob, M., 1999. The role of debris supply conditions in predicting debris flow activity. Earth Surf. Process. Landf. 24 (11), 1039-1054.

Braam, R.R., Weiss, E.E.J., Burrough, P.A., 1987. Spatial and temporal analysis of movement using dendrochronology. Catena 14, 573-584.

Bräker, O.U., 2002. Measuring and data processing in tree-ring research - a methodological introduction. Dendrochronologia 20 (1-2), 203-216.

Caine, N., 1980. The rainfall intensity-duration control of shallow landslides and debris flows. Geogr. Ann. 62A (1-2), 23-27.

Cannon, S.H., Gartner, J.E., Parret, C., Parise, M., 2003. Wildfirerelated debris-flow generation through episodic progressive sediment bulking processes, western USA. In: Rickenmann, D., Chen, C.L. (Eds.), Debris-flow Hazard Mitigation: Mechanisms, Prediction, and Assessment. Millpress, Rotterdam, pp. 71-82.

Cook, E.R., Kairiukstis, L.A., 1990. Methods of Dendrochronology Applications in the Environmental Sciences. Kluwer, London.

Corominas, J., Moya, J., 1999. Reconstructing recent landslide activity in relation to rainfall in the Llobregat River basin, Eastern Pyrenees, Spain. Geomorphology 30 (1-2), 79-93.
Costa, J.E., 1984. Physical geomorphology of debris flows. In: Costa, J.E., Fleisher, P.J. (Eds.), Developments and Applications of Geomorphology. Springer, Berlin, pp. 268-317.

Costa, J.E., 1988. Rheologic, geomorphic and sedimentologic differentiation of water floods, hyperconcentrated flows, and debris flows. In: Baker, V.R., Kochel, R.C., Patton, P.C. (Eds.), Flood Geomorphology. Wiley, London, pp. 113-122.

Ehmisch, M., 2005. Rekonstruktion und Frequenzanalyse von Murgangereignissen des Wildbaches Bruchji mit dendrogeomorphologischen Untersuchungsmethoden. Murkegel Bruchji, Blatten bei Naters, Wallis (CH). Diploma thesis. University of Frankfurt / Main.

Fantucci, R., Sorriso-Valvo, M., 1999. Dendrogeomorphological analysis of a slope near Lago, Calabria (Italy). Geomorphology 30 (1-2), 165-174.

Giardino, J.R., Shroder, J.F., Lawson, M.P., 1984. Tree-ring analysis of movement of a rock glacier complex on Mount Mestas, Colorado, USA. Arct. Alp. Res. 16 (3), 299-309.

Gutsell, S.L., Johnson, E.A., 2002. Accurately aging trees and examining their height-growth rates: implication for interpreting forest dynamics. J. Ecol. 90, 153-166.

Haeberli, W., Rickenmann, D., Zimmermann, M., Rösli, U., 1991. Murgänge. Ursachenanalyse der Hochwasser 1987. Ergebnisse der Untersuchungen. Mitt. BWW 4, 77-88.

Hantke, R., 1980. Eiszeitalter. Die jüngste Erdgeschichte der Schweiz und ihrer Nachbargebiete. Letzte Warmzeiten, Würm-Eiszeit, Eisabbau und Nacheiszeit der Alpen-Nordseite vom Rhein-zum Rhone-System. Ott, Thun.

Helsen, M.M., Koop, P.J., Van Steijn, H., 2002. Magnitude-frequency relationship for debris flows on the fan of the Chalance torrent, Valgaudemar (French Alps). Earth Surf. Process. Landf. 27 (12), 1299-1307.

Huggel, C., Kääb, A., Haeberli, W., Teysseire, P., Paul, F., 2002. Remote sensing based assessment of hazards from glacier lake outbursts: a case study in the Swiss Alps. Can. Geotech. J. 39 (2), 316-330.

Hungr, O., Morgan, G.C., Kellerhals, R., 1984. Quantitative analysis of debris torrent hazard for design of remedial measures. Can. Geotech. J. 21, 663-677.

Innes, J.L., 1983. Lichenometric dating of debris-flow deposits in the Scottish Highlands. Earth Surf. Process. Landf. 8, 579-588.

Innes, J.L., 1985. Lichenometric dating of debris-flow deposits on alpine colluvial fans in Southwest Norway. Earth Surf. Process. Landf. 10 (5), 519-524.

Jakob, M., Hungr, O., 2005. Debris-flow Hazards and Related Phenomena. Springer, Berlin.

Johnson, A.M., Rodine, J.R., 1984. Debris flow. In: Brundsen, D., Prior, D.B. (Eds.), Slope Instability. John Wiley and Sons, New York, pp. 257-361.

Jonasson, C., Kot, M., Kotarba, A., 1991. Lichenometric studies and dating of past debris flow deposits in the High Tatra Mountains, Poland. Geogr. Ann. 73A, 141-146.

Jossen, E., 2000. Naters-Das grosse Dorf im Wallis. Rotten Verlag, Visp.

Labhart, T.P., 2004. Geologie der Schweiz, 6th edn. Ott Verlag, Thun.

May, C.L., Gresswell, R.E., 2004. Spatial and temporal patterns of debris-flow deposition in the Oregon Coast Range, USA. Geomorphology 57 (3-4), 135-149.

Perret, S., Stoffel, M., Kienholz, H., 2006. Spatial and temporal rockfall activity in a forest stand in the Swiss Prealps- a dendrogeomorphological case study. Geomorphology 74 (1-4), 219-231. 
Rickenmann, D., 1999. Empirical relationship for debris flows. Nat. Hazards 19 (1), 47-77.

Rinntech, 2006. LINTAB - precision ring by ring. http://www. rinntech.com/Products/LINTAB.htm.

Schweingruber, F.H., 1978. Microscopic Wood Anatomy. Birmensdorf.

Schweingruber, F.H., 1996. Tree rings and environment. Dendroecology. Paul Haupt, Bern.

Schweingruber, F.H., 2001. Dendroökologische Holzanatomie. Paul Haupt, Bern.

Schweingruber, F.H., Eckstein, D., Serre-Bachet, F., Bräker, O.U., 1990. Identification, presentation and interpretation of event years and pointer years in dendrochronology. Dendrochronologia 8 , 9-39.

Schweingruber, F.H., Börner, A., Schultze, E.-D., 2006. Atlas of Woody Plant Stems. Evolution, Structure, and Environmental Modifications. Swiss Federal Research Institute WSL, Springer, Berlin.

Shroder, J.F., 1978. Dendrogeomorphologic analysis of mass movement on Table Cliffs Plateau, Utah. Quat. Res. 9, 168-185.

Shroder, J.F., 1980. Dendrogeomorphology; review and new techniques of tree-ring dating and geomorphology. Prog. Phys. Geogr. 4 (2), 161-188.

Stefanini, M.C., 2004. Spatio-temporal analysis of a complex landslide in the Northern Apennines (Italy) by means of dendrochronology. Geomorphology 63 (3-4), 191-202.

Stefanini, M.C., Ribolini, A., 2003. Dendrogeomorphological investigations of debris-flow occurrence in the Marittime Alps (northwestern Italy). In: Rickenmann, D., Chen, C.L. (Eds.), Debris-flow Hazard Mitigation: Mechanisms, Prediction, and Assessment. Millpress, Rotterdam, pp. 231-242.

Stoffel, M., Beniston, M., 2006. On the incidence of debris flows from the early Little Ice Age to a future greenhouse climate: a case study from the Swiss Alps. Geophys. Res. Lett. 33, L16404.

Stoffel, M., Perret, S., 2006. Reconstructing past rockfall activity with tree rings: some methodological considerations. Dendrochronologia 24 (1), 1-15.
Stoffel, M., Gärtner, H., Lièvre, I., Monbaron, M., 2003. Comparison of reconstructed debris-flow event years (Ritigraben, Switzerland) and existing flooding data in neighboring rivers. In: Rickenmann, D., Chen, C.L. (Eds.), Debris-flow Hazard Mitigation: Mechanisms, Prediction and Assessment. Millpress, Rotterdam, pp. 243-253.

Stoffel, M., Lièvre, I., Conus, D., Grichting, M.A., Raetzo, H., Gärtner, H.W., Monbaron, M., 2005a. 400 years of debris flow activity and triggering weather conditions: Ritigraben, Valais, Switzerland. Arct. Antarc. Alp. Res. 37 (3), 387-395.

Stoffel, M., Lièvre, I., Monbaron, M., Perret, S., 2005b. Seasonal timing of rockfall activity on a forested slope at Täschgufer (Swiss Alps) - a dendrochronological approach. Z. Geomorphol. 49 (1), 89-106.

Stoffel, M., Schneuwly, D., Bollschweiler, M., Lièvre, I., Delaloye, R., Myint, M., Monbaron, M., 2005c. Analyzing rockfall activity (1600-2002) in a protection forest — a case study using dendrogeomorphology. Geomorphology 68 (3-4), 224-241.

Stoffel, M., Bollschweiler, M., Hassler, G.R., 2006. Differentiating past events on a cone influenced by debris-flow and snow avalanche activi ty - a dendrogeomorphological approach. Earth Surf. Process. Landf. 31 (11), 1424-1437.

Strunk, H., 1997. Dating of geomorphological processes using dendrogeomorphological methods. Catena 31, 137-151.

Van Steijn, H., 1996. Debris-flow magnitude-frequency relationships for mountainous regions of Central and Northwest Europe. Geomorphology 15 (3-4), 259-273.

Winchester, V., Harrison, S., 1994. A development of the lichenometric method applied to the dating of glacially influenced debris flows in Southern Chile. Earth Surf. Proces. Landf. 19, 137-151.

Wilson, R.C., Wieczorek, G., 1995. Rainfall thresholds for the initiation of debris flows at La Honda, California. Environ. Eng. Geosci. 1 (1), 11-27.

Zimmermann, M., Mani, P., Romang, H., 1997. Magnitude-frequency aspects of alpine debris flows. Eclogae Geol. Helv. 90 (3), $415-420$. 